УДК 004.4.277.4

\title{
АНАЛІЗ МЕТОДІВ УВЕДЕННЯ ЗВУКОВОЇ ІНФОРМАЦІї, ЗАПИСАНОЇ У НОТНИХ СИМВОЛАХ
}

ㄷ О. С. Хлус, магістрантка, Р. А. Хохлова, к.т.н., доцент, НТУУ «КПІ», Київ, Україна

Проанализированы возможные факторы влияния на качество воспроизведения звука. Проанализированы методы ввода звуковой информации, которые предварительно записаны нотными знаками. Проведено экспертное сравнение программного обеспечения для распознавания нотных символов по приоритетным параметрам и точностью распознавания информации.

The analysis of possible factors which influence on sound quality is held. Methods of entering sound information written with music symbols were analyzed. It was held the expert comparison of software to recognizing music symbols in priority parameters and recognition quality of information.

\section{Постановка проблеми}

Згідно з ДСтУ 7157:2010 [1] електронне видання - електронний документ, що пройшов редакційно-видавничу обробку, призначений для поширення у незмінному вигляді та має вихідні відомості. Мультимедійні видання - електронні видання, у яких інформація різної природи присутня рівноправно та взаємопов'язана для вирішення певних задач, при чому цей зв'язок забезпечується відповідним програмним забезпеченням. Крім того електронні мультимедійні видання характеризуються наявністю відео та аудіо інформації для покращення сприйняття викладеного матеріалу.

На даний час інтенсивно розвивається галузь мультимедійних видань, яка практично захопила навчальну область, освіту, де існує велика кількість електронних інформаційних мультимедійних енциклопедій, довідників і навчальних посібників. Нотні видання не $€$ виключенням. Мультимедійне нотне видання окрім нотного тексту містить звукову інформацію, що безпосередньо пов'язана $з$ ним. Отже електронні видання можуть містити визначену звукову інформацію, тобто звуковий супровід, що заздалегідь записаний у нотних символах. Такі видання можна називати музичними.

Проектування технологічного процесу виготовлення електронного музичного видання $€$ актуальним питанням, оскільки у мультимедійних виданнях можна забезпечити підвищення зручності його використання завдяки можливості змінювати параметри перегляду для покращення читабельності, та завдяки навігації, а саме - засто- 
сування функцій гіперпосилань та швидкого пошуку. Також підвищення розуміння і засвоєння матеріалу забезпечується додаванням звукових файлів, що програють приклади основних співзвуч та завдання на сольфеджіо.

Існує багато способів виготовлення електронних видань. При проектуванні мультимедійних музичних видань вибір способу виготовлення та формату звукових файлів тісно пов'язані між собою. Тому виникає проблема визначення оптимального методу введення звукової інформації, виходячи з вхідних форматів файлів, їх сумісності 3 форматом електронного видання та призначенням майбутнього видання.

\section{Аналіз попередніх досліджень}

Нажаль, розвиток друкованих нотних видань на сьогоднішній день $є$ дещо призупиненим - більшість музичних шкіл та інших учбових закладів користуються нотними виданнями двадцятирічної давності. Однак з розвитком електронних мультимедійних видань можна спостерігати і розвиток нотних електронних видань, яких все більше з'являється у мережі Інтернет [2, 3]. Причиною інтеграції друкованих видань у електронні $€$ те, що практично всі інформаційні технології перейшли на цифрову форму, оснастились комп'ютерною технікою, програмним забезпеченням професійного рівня та технічними засобами обробки зображень, тексту, звуку. Електронні видання $€$ дешевшими ніж дру- ковані і дозволяють більш динамічно побудувати процес вивчення матеріалу, що забезпечує прискорення процесу сприйняття та запам'ятовування викладеного.

Однак, інформації щодо проектування, розроблення і підготовки музичних електронних видань надзвичайно мало. Також практично відсутня інформація про дослідження в цій царині, особливо щодо узагальнення i систематизації технологій, засобів і методів виготовлення музичних мультимедійних видань.

\section{Мета роботи}

За мету роботи було поставлено проведення аналізу та систематизації методів введення звукової інформації, записаної у нотних символах, для виготовлення мультимедійних музичних видань; здійснення детального порівняльного аналізу програмного забезпечення (ПЗ) розпізнавання нотних символів.

\section{Результати проведених досліджень}

Існує класифікація електронних видань згідно з ДСТУ 7157:2010 [1]. На підставі аналізу ДСТУ 7157:2010 [1] та науково-технічної літератури [1, 4] з особливостей та технологій виготовлення електронних музичних видань було уведено додатково дві ознаки: формат електронного видання та формат звукових файлів у виданні (рис. 1). Так, додані класифікаційні ознаки мають беззаперечний вплив на визначення оптимальної технології виготовлення мультимедійного музичного видання. 

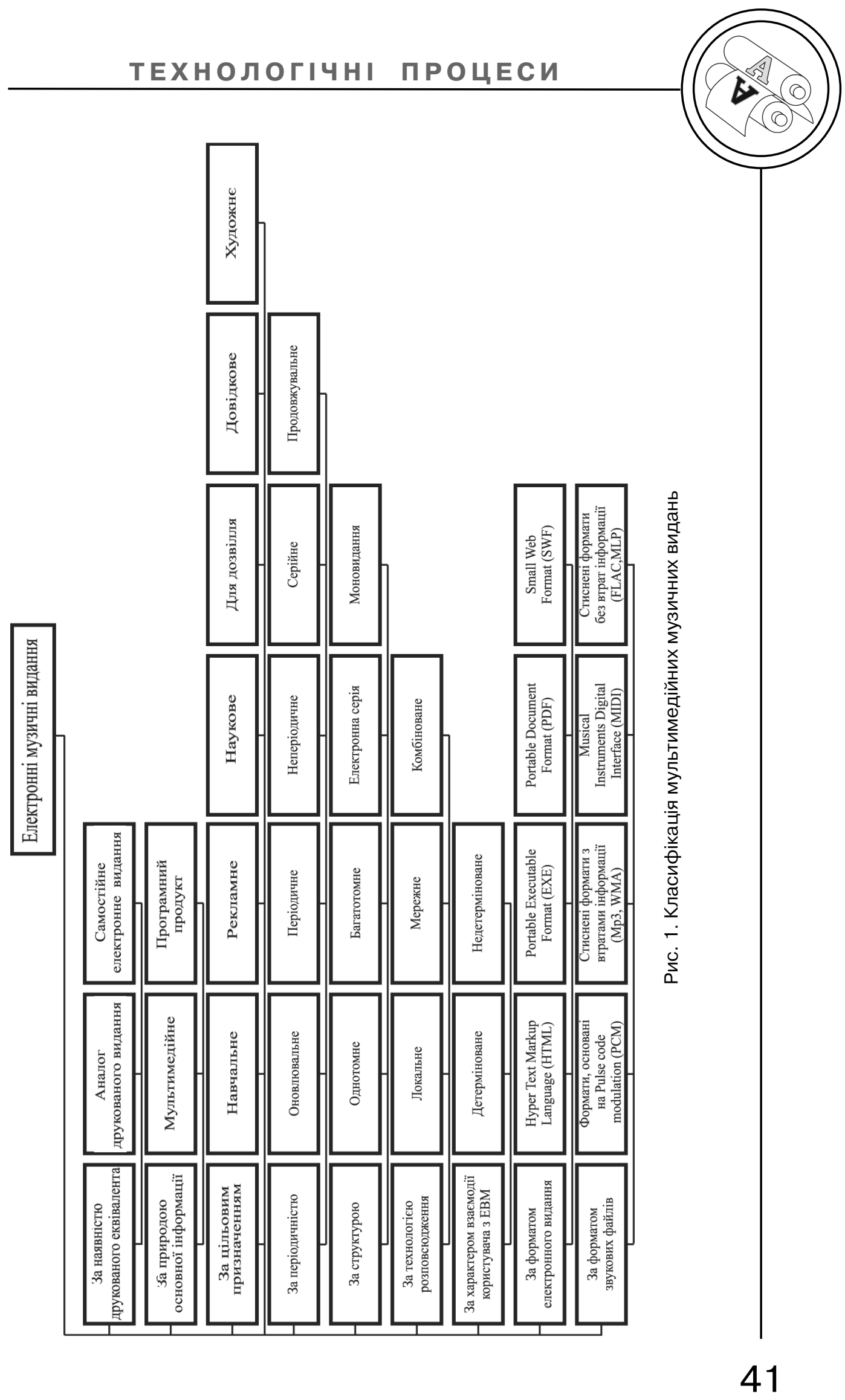
Звукова інформація у виданні може бути у форматі, що отримується методом пульсового кодування, тобто перетворенням аналогового сигналу у цифровий. Це є не стиснена інформація, що має шуми та займає багато місця на робочих станціях, прикладом $\in$ WAWформат [1, 4].

Формати стиснених файлів 3 втратами інформації характеризуються тим, що така звукова інформація займає значно менше місця на робочих станціях та не містить частот, що не сприймаються людським вухом. Також існують формати, що стиснені без втрат інформації, при цьому оригінальні данні повністю відтворюються із стисненого стану.

MIDI-формат використовується для управління синтезатором звукової карти. Тобто файл формату MIDI містить інформацію про послідовність відтворення кожної ноти, її довжину та темп звуку, гучність, їі положення у просторі. Файли цього формату займають найменше місця на робочих станціях та не містять шумів.

Для класифікації за ознакою формат електронного видання, визначено формати електронних видань, які мають можливість відтворювати звукові файли.

При виготовленні електронних музичних видань, крім стандартних операцій - обробки текстової та графічної інформації, $€$ необхідність введення визначеної звукової інформації та її обробки (рис. 2) [2]. Саме тому при підготовці мультимедійних музичних видань ви- никає актуальна проблема вибору оптимального способу введення звукової інформації.

Звук - це коливальний рух частинок пружного середовища, що поширюється у вигляді хвиль у газі, рідині чи твердому тілі. Існує два види представлення звукової інформації: аналогова та цифрова. Для запису звукової інформації у електронне видання необхідно ії представити у цифровому виді. Задачею перетворення звуку у електронний вид $€$ повторення всіх його хвильових характеристик. Але електронний сигнал не $\epsilon$ аналоговим, і може записуватись за допомогою коротких дискретних значень. Такий запис має назву імпульсно-кодовою модуляцією і являє собою послідовний запис дискретних значень. Розрядність пристрою, а отже і звукового файлу, що визначається у бітах, говорить про кількість дискретних значень, що використовувались для запису звукового сигналу. Чим вища розрядність, тим більше звук відповідає оригіналу. Отже цифровий звук - представлення аналогового звукового сигналу у вигляді бітової послідовності, котра відповідає рівням електричних звукових коливань у певному інтервалі часу.

Як було зазначено вище для виготовлення мультимедійного музичного видання звукову інформацію необхідно представити у цифровому виді. Належна якість відтворення звуку у музичному виданні $€$ одним 3 пріоритетних параметрів, на який необхідно звертати увагу при проектуванні технологічно- 


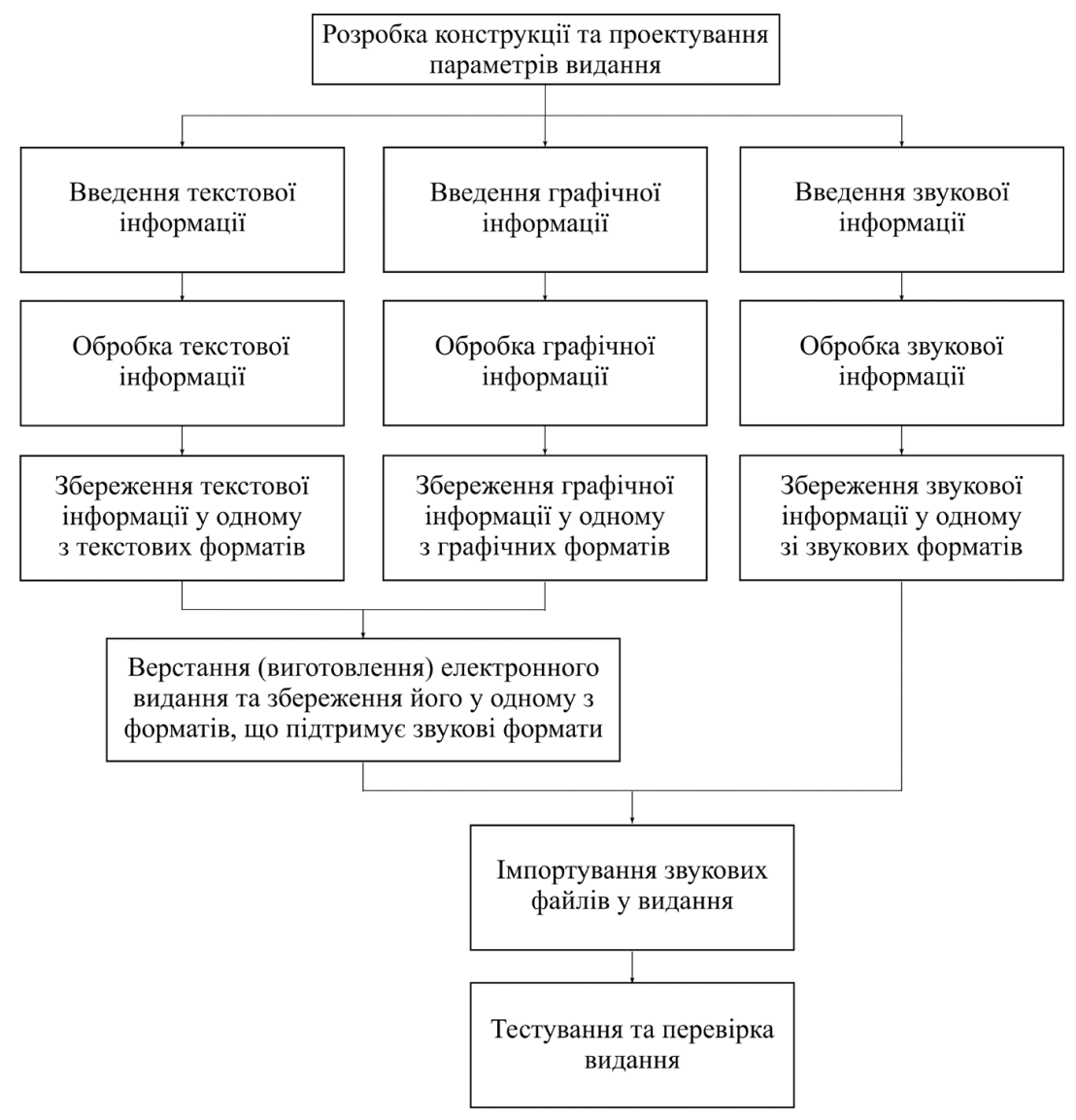

Рис. 2. Загальна схема виготовлення електронного музичного видання

го процесу запису звуку у одному з цифрових форматів, що супроводжується визначенням та встановленням відповідних параметрів звукових файлів, таких як темп звучання, рівень гучності, ступінь стиснення (для стиснених форматів файлів), формат звуку (моно або стерео), рівень ревербування, частота дискретизації. Проаналізувавши фахові технічні джерела, було систематизовано чинники, що впливають на якість відтворення звуку, у вигляді розробленої причинно-наслідкової діаграми (рис. 3). Зазначено, що основними чинниками якості відтворення звуку $€$ наявність відповідного програмного забезпечення, належний стан обладнання, технологія оцифровування звукової інформації, робота персоналу. Для отримання якісного відтворення звукових файлів параметри звукових файлів повинні відповідати вимогам технологічного завдання. Окрім цього на вдале виконання музичного мультимедійного видання мають безпосередній вплив програмне забезпечення, що використовується як для оцифровування так і для прослуховування звуку, наявність різноманітних утилітів, техно- 


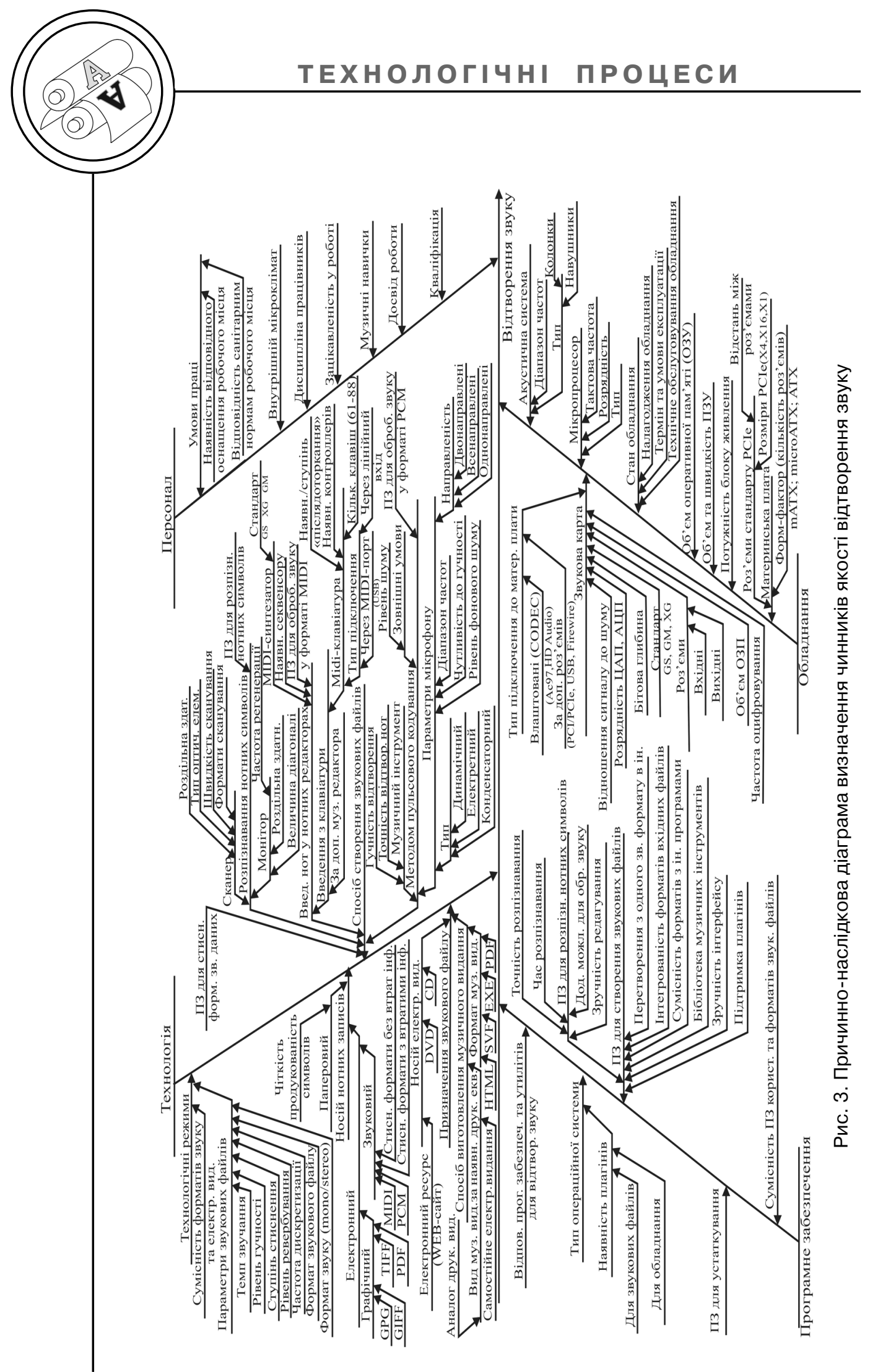


логічні особливості обладнання, спосіб представлення звуку на вході тощо.

Отже, зважаючи на тип носія нотних записів, можна зазначити, що за наявності нотного запису на папері або у вигляді будь-якого графічного формату файлу оцифровувати звукову інформацію можна трьома основними способами: метод пульсового кодування; введення нотних символів з клавіатури; розпізнавання нотних символів.

Для оцифровування звуку шляхом перетворення аналогового сигналу у цифровий, тобто методом пульснового кодування, необхідно підключити мікрофон у відповідний роз'єм звукової карти, встановити відповідний музичний редактор у режимі запису та шляхом програвання нотного запису на фортепіано чи на іншому музичному інструменті здійснити запис звукової інформації. Цей спосіб вимагає використання різних музичних інструментів та програм для обробки оцифрованих файлів, оскільки у будь-якому разі будуть присутні шуми у звуковому записі. Крім того файл буде займати досить багато місця на робочій станції. Аби результат був якісним необхідно проводити запис звукової інформації у професійно обладнаних звукозаписуючих студіях. Також даний метод потребує професійних музичних навичок.

Другий спосіб полягає у введенні нотної інформації вручну $з$ клавіатури у спеціальних нотних редакторах (наприклад Sibelius), що мають можливість збереження нотного запису у одно- му зі звукових форматів. Також можна вводити звукову інформацію використовуючи MIDIклавіатуру, підключивши її через MIDI-порт звукової карти. У цьому випадку звук також буде мати формат MIDI, 3 можливістю обробки у музичних редакторах. Однак використання MIDIклавіатури вимагає володіння певними музичними навичками.

При підготовці звукових файлів методом розпізнавання нотних символів першочергово необхідно відсканувати мелодію у нотному записі, розпізнати її за допомогою відповідного програмного забезпечення та зберегти у звуковому форматі.

Останні два способи порівняно 3 першим $€$ рентабельнішими, оскільки не потребують додаткового музичного периферійного обладнання та звукової карти з потужним аналого-цифровим перетворювачем. Для отримання якісного результату необхідно лише відповідне програмне забезпечення. Крім того файли на виході можуть мати формат MIDI. Такі файли не будуть містити шумів та займатимуть декілька Кбайт на робочій станції. Якість цих файлів буде залежати лише від точності введення нотних символів та модуля звукової карти, що управляється за допомогою MIDI [5, 6].

Для вибору найоптимальнішого способу введення звукової інформації здійснено порівняння двох останніх методів за допомогою циклограми технологічних процесів (рис. 4) при підготовці обраного нотного видання. 


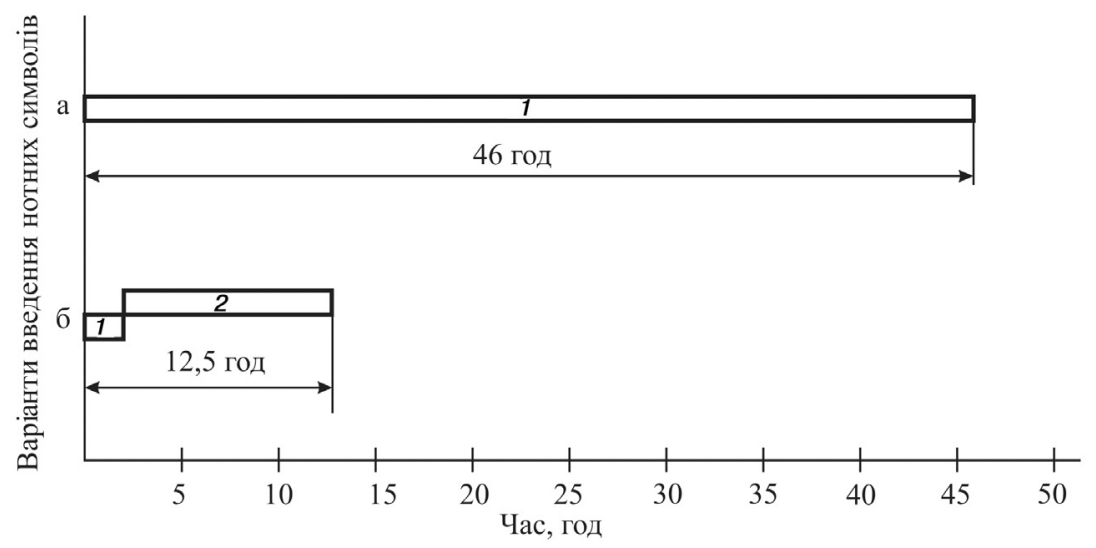

Рис. 4. Циклограма технологічних процесів введення нотної інформації, де: (а) введення нотної інформації вручну: 1 - введення нотної інформації вручну та збереження нотних записів у звуковому форматі; (б) введення нотної інформації скануванням з подальшою обробкою відсканованих файлів: 1 - сканування нотних символів; 2 - розпізнавання відсканованих файлів та збереження нотної інформації у відповідному звуковому форматі

Як видно з рис. 4 спосіб, що базується на розпізнаванні нотних символів $є$ набагато швидшим. Однак коефіцієнт технологічності для цього способу $\epsilon$ меншим - 0,5, оскільки потребує використання додаткового обладнання - професійного сканера. Але при виготовленні електронного видання процес сканування у більшості випадків буде мати місце для вводу текстової чи графічної інформації. Отже можна вважати, що спосіб введення звукової інформації шляхом сканування та розпізнавання $€$ найоптимальнішим.

Для обраного способу введення звукової інформації розроблено детальний алгоритм (рис. 5).

Найголовнішою операцією алгоритму є розпізнавання, що впливає на час оцифровування нотних записів та на усі подальші операції. Якість розпізнавання залежить лише від програмного забезпечення, тому визначення засобу для розпізнавання записаної нотними знаками звукової інформації $€$ актуальним питанням.

Для вибору оптимального засобу для розпізнавання нотних символів обрано таке програмне забезпечення: CapellaScan, SharpEye 2, Neuratron PhotoScore Professional, Finale, Musitek SmartScore X Professional Edition, що мають функції розпізнавання нотних символів, можливість звукового відтворення розпізнаних символів та збереження у звуковому форматі, крім того вони поширені у глобальній мережі Інтернет. Обрані програми оцінювались експертами (див. рис. 6), згідно розробленої матриці, за такими параметрами: 1 - точність розпізнавання нотних знаків; 2 - сумісність 3 іншими програмами для редагування нотного тексту; 3 - інтег- 


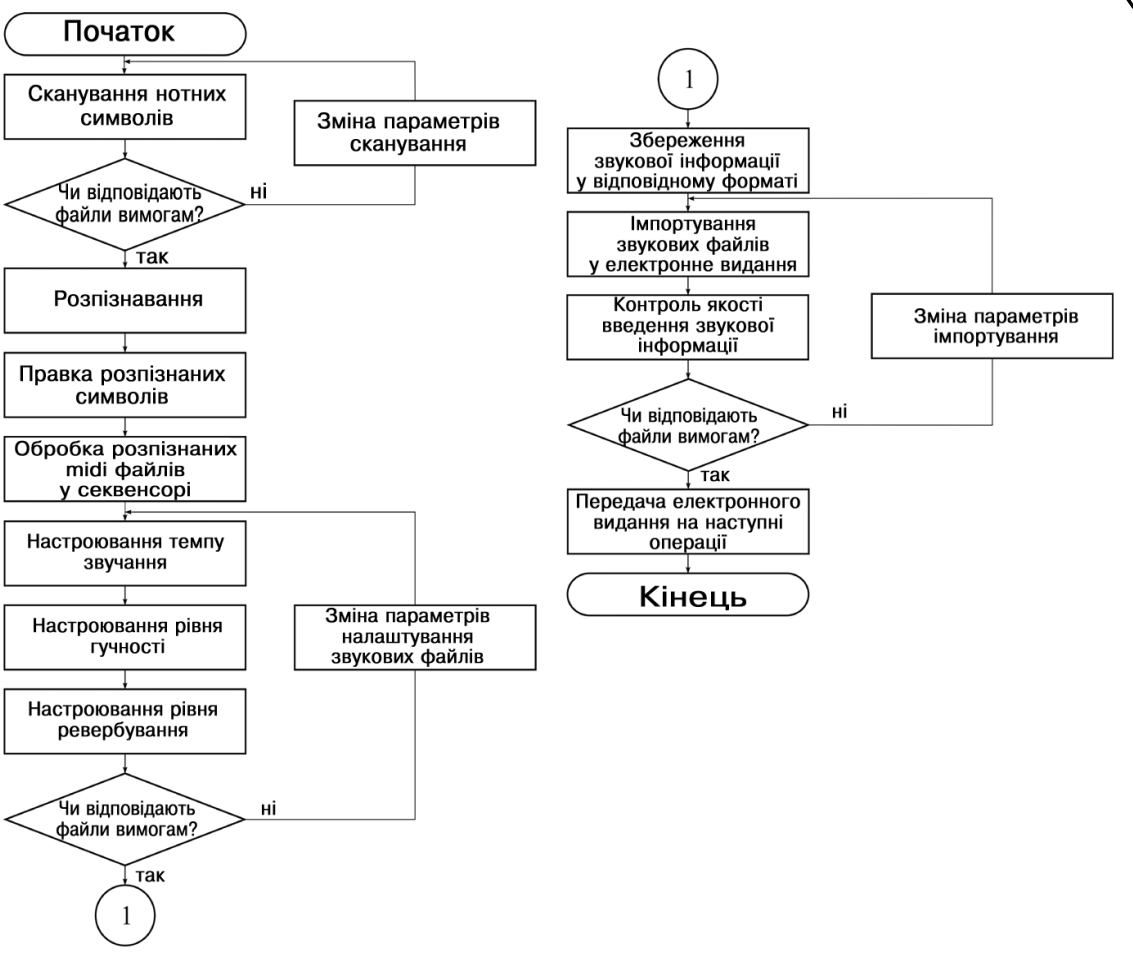

Рис. 5. Алгоритм введення звукової інформації на робочу станцію з подальшим ії використанням для виготовлення мультимедійного музичного видання

рованість форматів вихідних файлів; 4 - швидкість розпізнавання нотного тексту; 5 рівень зручності та «інтуїтивності» інтерфейсу; 6 - зручність редагування розпізнаного нотного тексту.

Згідно експертної оцінки, найважливішим параметром для розпізнавання нотних записів є точність. Тому для подальшого дослідження точності розпізнавання нотних записів було обрано скановане зображення нотних символів у форматі tiff, з розширенням 300 dpi та розміром - $1824 \times 2510$ пікселів. Розпізнавання цього нотного запису проводилось 3 використанням кожної зазначеної програми.

За отриманими результатами обробки зісканованого нотного запису жодна з програм не виконала розпізнавання без помилок. Тому було проведено систематизацію помилок, що виникають при некоректному розпізнаванні того чи іншого нотного символу (рис. 7) для прискорення їх пошуку та виправлення при подальшому оцифровуванні нотних символів методом розпізнавання. Так, усі помилки можна розділити на ритмічні та гармонічні. При ритмічних помилках або порушується темп звучання мелодії 


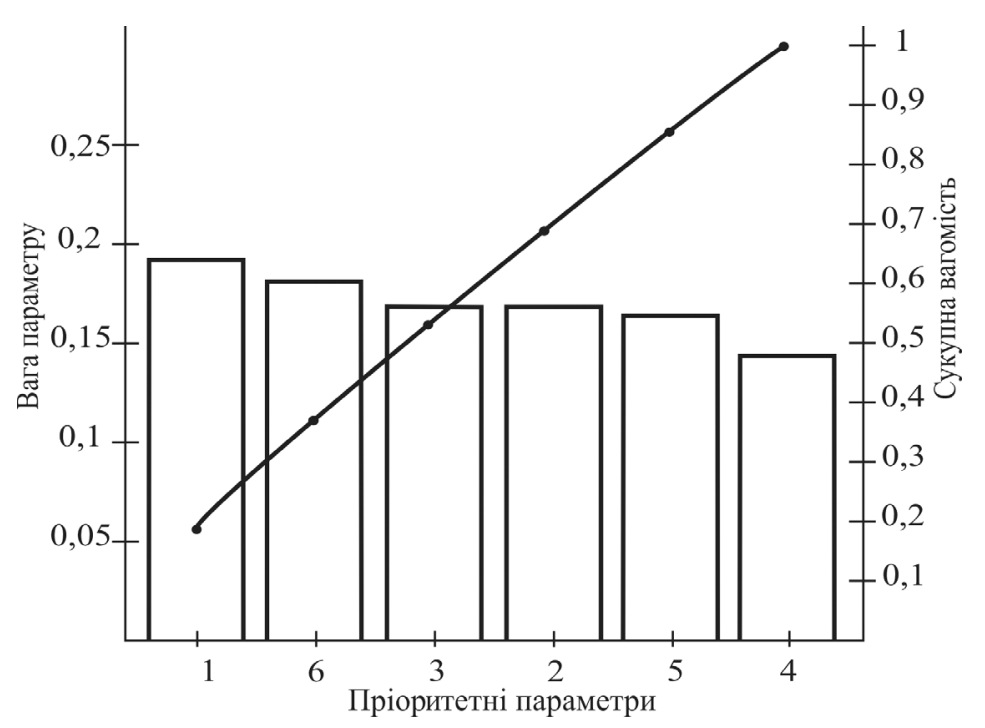

Рис. 6. Параметри порівняння програмних продуктів для розпізнавання нотних символів

або музичний запис не відтворюється, поки помилки не будуть виправлені. При гармонічних помилках порушується лише гармонія на всю мелодію або на окремий такт.

Наприклад, розмір твору визначає кількість довжин у такті, тому при неправильному розпізнаванні збивається ритм і мелодія не буде програватись. Реприза визначає повторення певної частини мелодії, програма може не розпізнати крапок, що порушить ритміку музичного твору. При нерозпізнаванні тактової смужки порушиться розмір такту, не виділиться сильна доля. Не правильне розпізнавання з'єднувальної смужки та крапки після ноти приводить до зміни розміру такту, в результаті чого мелодія не буде відтворюватись. Також без

\begin{tabular}{|c|c|c|c|c|c|}
\hline \multicolumn{4}{|c|}{ Ритмічні } & \multicolumn{2}{|c|}{ Гармонічні } \\
\hline Розмір твору & $\frac{\theta_{3}}{(0)}$ & Ліга & $\underline{\partial 2}$ & $\begin{array}{c}\text { Скрипковий } \\
\text { ключ }\end{array}$ & \\
\hline Тактова смужка & 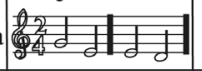 & $\begin{array}{c}\text { 3'єднувальна } \\
\text { смужка }\end{array}$ & $\overline{\equiv \sqrt{2}}$ & $\begin{array}{c}\text { Старофранцузь- } \\
\text { кий ключ }\end{array}$ & $\underline{\equiv \equiv}$ \\
\hline Реприза & 过 & $\begin{array}{c}\text { Крапка після } \\
\text { ноти }\end{array}$ & $\overline{\overline{\equiv ㇒}}$ & Басовий ключ & $\overline{\equiv 0^{\circ}}$ \\
\hline $\begin{array}{c}\text { Половинна } \\
\text { пауза }\end{array}$ & $\overline{\bar{\equiv}}$ & Ціла пауза & 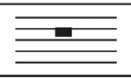 & $\begin{array}{c}\text { Баритоновий } \\
\text { ключ }\end{array}$ & $\overline{\overline{\equiv 9^{\circ}}}$ \\
\hline Четвертна пауза & $\overline{\bar{\equiv}}$ & Восьма пауза & $\overline{\overline{\equiv q}}$ & $\begin{array}{c}\text { Знаки } \\
\text { аліттерації }\end{array}$ & \\
\hline Фермата & $\overline{\equiv \dot{d}}$ & Стоката & 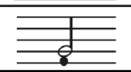 & $\begin{array}{c}\text { Мажорний } \\
\text { тризвук }\end{array}$ & 产 \\
\hline
\end{tabular}

Рис. 7. Систематизація помилок, що виникають при розпізнаванні нотних символів 
ліги заліковані автором ноти будуть звучати окремо, а не як одна четвертна. Програма може не розпізнати знак фермати або стокати і при відтворенні також порушиться темп мелодії. Восьма та четвертна паузи дуже схожі між собою, так як і половинна з цілою - тому також виникає небезпека неправильного розпізнавання цих символів в результаті чого мелодія не програватиметься.

Також можлива ситуація, коли програма при розпізнаванні сплутає старофранцузький та скрипковий ключі, в результаті чого буде визначено ноту «соль» не на тій лінії - у такому разі гармонія буде порушена. У басового та баритонового ключа ситуація схожа. Тільки в цьому випадку ці ключі відповідають за ноту «фа». При неправильному розпізнанні знаків алітерації (діез, бимоль) мелодія відтвориться у іншій гаммі, ця помилка буде поширюватись на весь музичний витвір, якщо знаки стоять при ключі, а бо на один такт якщо знак стоїть при ноті. у будь-якому випадку виникає небезпека неправильного розпізнавання висоти ноти, однак, помилка буде більш грубою, якщо програма не правильно розпізнає ноту у тризвуку, в результаті чого буде звучати зовсім інший акорд [7].

В результаті проведеного тестування програмного забезпечення побудовано діаграму співвідношення кількості помилок, що виникають при розпізнаванні нотних символів кожною 3 обраних програм (рис. 8).

Найкращі результати за розпізнаванням нотних символів та відтворенням звуку ви-

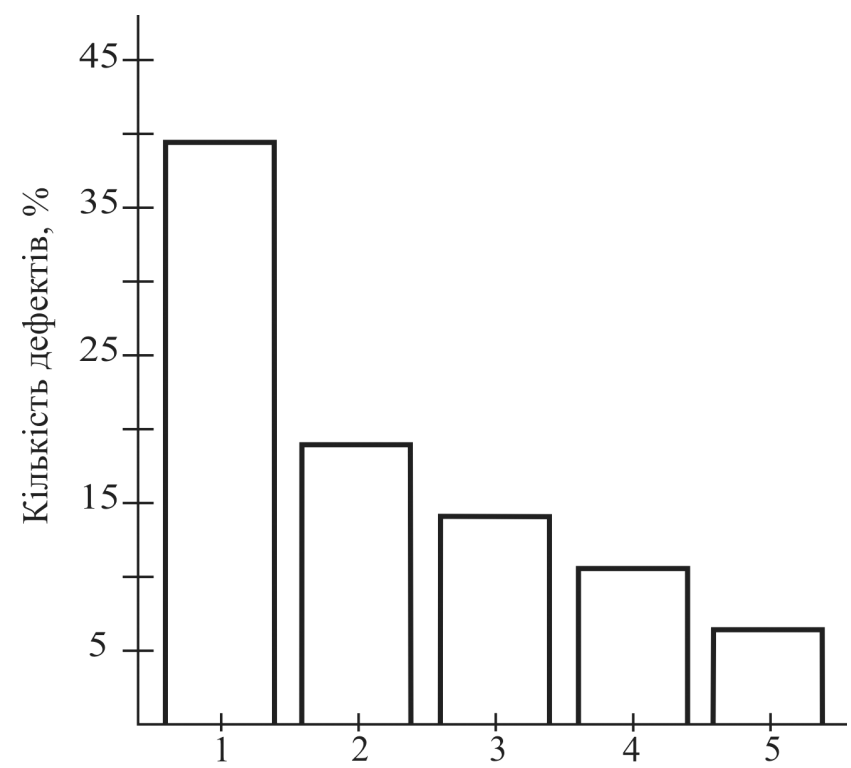

Рис. 8. Діаграма співвідношення кількості помилок, що виникають при розпізнаванні нотних символів програмними продуктами: 1 - SharpEye 2;

2 - Capella-Scan; 3 - Musitek SmartScore X Professional Edition; 4 - Finale; 5 - Neuratron PhotoScore Professional 
явлено при використанні програм Finale та Neuratron PhotoScore Professional. Це дає підстави стверджувати про коректність їх застосування для підготовки мультимедійного видання, що містить визначену звукову інформацію, тобто заздалегідь записану у нотних знаках.

\section{Висновки}

Отримані результати досліджень методів оцифровування звукової інформації дають можливість оптимізувати процес виготовлення мультимедійних музичних видань. Складена діаграма Ісікава дозволяє встановити можливі причини виникнення невідповідності параметрів звукових файлів вже на етапі проектуван- ня способу оцифровування звуку. Обраний метод введення звукової інформації та розроблений алгоритм дозволяють пришвидшити процес виготовлення мультимедійних музичних видань та підвищити якість звукових файлів у виданні. Оптимізація досягається шляхом заміни музичних навичок та музичних інструментів на програмне забезпечення, що спеціалізується на розпізнаванні нотних символів. Також оптимізують технологічний процес оцифровування звукової інформації для виготовлення мультимедійних музичних видань класифікація помилок, що виникають при розпізнаванні нотних символів та вдосконалена класифікація мультимедійних музичних видань.

1. Інформація та документація. Електронні видання. Основні види та вихідні відомості : ДСТУ 7157:2010. - [Чинний від 01.07.2010]. — К. : Держстандарт України, 2010. - 18 с. - (Національні стандарти України). 2. Вуль В. А. Электронные издания / В. А. Вуль. - М.-СПб. : Петербургский институт печати, 2001. - 308 с. 3. Нотне видання [Електронний ресурс] // [Региональный Центр по разработке электронных средств обучения] / Документознавство : основні терміни та поняття. - Режим доступу : http://softacademy.Inpu.edu.ua/Programs/Dokumentoznavstvo/ 16.html (17.01.13). - Загол. з екрану. 4. Стандартные форматы звуковых файлов [Електронний ресурс] // [Курс по цифровому звуку] / Цифровой звук. - Режим доступу : http://audacity.ru/p7aa1.html (17.01.13). - Загол. з екрану. 5. Семилетов П. Ересь звукозаписи. - 2012. - Режим доступу до видання : http:// soundheresy.ho.ua/ (17.01.13). - Назва з екрану. 6. Основы работы со звуком [Електронний ресурс] // [Music4sale портал музыкантов] / Работа со звуком. - Режим доступу : http://www.music4sale.ru/articles/ knowledge_base/52 (17.01.13). - Загол. з екрану. 7. Фридкин Г. А. Практическое руководство по музыкальной грамоте / Г. А. Фридкин. - М. : Музыка, 1997. - 296 с.

1. Informatsiia ta dokumentatsiia. Elektronni vydannia. Osnovni vydy ta vykhidni vidomosti : DSTU 7157:2010. - [Chynnyi vid 01.07.2010]. - K. : Derzhstandart Ukrainy, 2010. - 18 s. - (Natsionalni standarty Ukrainy). 2. Vul' V. A. Jelektronnye izdanija / V. A. Vul'. - M.-SPb. : Peterburgskij institut pechati, 2001. - 308 s. 3. Notne vydannia [Elektronnyi resurs] // [Regional'nyj Centr po razrabotke jelektronnyh sredstv obuchenija] / Dokumentoznavstvo : osnovni terminy ta poniattia. - Rezhym dostupu : http://softacademy.Inpu.edu.ua/ Programs/Dokumentoznavstvo/16.html (17.01.13). - Zahol. z ekranu. 
4. Standartnye formaty zvukovyh fajlov [Elektronnyi resurs] // [Kurs po cifrovomu zvuku] / Cifrovoj zvuk. - Rezhym dostupu : http://audacity.ru/p7aa1.html (17.01.13). - Zahol. z ekranu. 5. Semiletov P. Eres' zvukozapisi. - 2012. Rezhym dostupu do vydannia : http://soundheresy.ho.ua/ (17.01.13). - Nazva z ekranu. 6. Osnovy raboty so zvukom [Elektronnyi resurs] // [Music4sale portal muzykantov] / Rabota so zvukom. - Rezhym dostupu : http://www.music4sale.ru/articles/ knowledge_base/52 (17.01.13). — Zahol. z ekranu. 7. Fridkin G. A. Prakticheskoe rukovodstvo po muzykal'noj gramote / G. A. Fridkin. - M. : Muzyka, 1997. - 296 s.

Рецензент - О. М. Величко, д.т.н., професор, НТУУ «КПІ»

Надійшла до редакції 22.12.12 